\title{
Antimicrobial Activity of Ethanolic Extract of Medicinal Plants against Human Pathogenic Bacteria
}

\author{
Hira Sakha ${ }^{1}$, Rejila Hora ${ }^{1}$, Shilpa Shrestha ${ }^{1}$, Shreeya Acharya ${ }^{1}$, Dinesh Dhakal ${ }^{1 *}$, Srijana \\ Thapaliya ${ }^{1}$, Kamil Prajapati ${ }^{1}$ \\ ${ }^{1}$ Department of Microbiology, Sainik Awasiya Mahavidhyalaya, Sallaghari, Bhaktapur
}

\begin{abstract}
*Corresponding author: Dinesh Dhakal, Department of Microbiology, Sainik Awasiya
\end{abstract} Mahavidyalaya, Sallaghari, Bhaktapur; E-mail: dineshdhakal7@hotmail.com

\begin{abstract}
Objectives: To evaluate the antimicrobial activity of medicinal plants against human pathogenic bacteria and perform Minimum Inhibitory Concentration (MIC) of plant extracts.

Methods: Rhizome of Curcuma longa, dried buds of Synzygium aromaticum, seeds of Zanthoxylum armatum and leaves of Elaeocarpus ganitrus, Psidium guajava, Azadirachta indica, and Artemisia vulgaris were collected from hilly regions of Nepal. The plant parts were air-dried at room temperature and grinded to powder form. The ethanolic extracts of medicinal plants were prepared by percolation process using separating funnel and tested against human pathogenic bacteria by disc diffusion method. Then, Minimum Inhibitory Concentration (MIC) of the plant extracts were determined.

Results: All plants extracts exhibited antibacterial properties against bacteria under study. However, extract from S. aromaticum (Clove), P. guajava (Guava) and E. ganitrus (Rudraksh) leaves showed most promising result against Staphylococcus aureus with zone of inhibition of $14 \mathrm{~mm}, 16 \mathrm{~mm}$ and 16 $\mathrm{mm}$ respectively. Likewise, S. aromaticum (Clove), C. longa (Turmeric) and P. guajava (Guava) showed good antibacterial activity against Escherichia coli with zone of inhibition of $11 \mathrm{~mm}, 11 \mathrm{~mm}$ and $10 \mathrm{~mm}$ respectively. A. vulgaris (Titepati) and A. indica (Neem leaves) showed promising activity against Pseudomonas aeruginosa with zone of inhibition of $11 \mathrm{~mm}$. Z. armatum (Timur) showed good result against $E$. coli with zone of inhibition $10 \mathrm{~mm}$. MIC values of ethanolic extracts of $S$. aromaticum and $E$. ganitrus were found to be at the range of $12.5-25 \mathrm{mg} / \mathrm{ml}$.
\end{abstract}

Conclusion: This study has helped to understand the use of these plants as traditional medicine as an economic and safe alternative to treat infectious diseases.

Key words: Plant extracts, antimicrobial activity, zone of inhibition, Minimum Inhibitory Concentration

\section{INTRODUCTION}

Bacterial infections cause problem for human kind beyond historical age. Researches to find antimicrobial medicine have been launch for over 50 years (Rudrappa and Bais 2008). However, even many antibiotics have been discovered, we still are facing multidrug resistance bacterial infections (Dowzicky and Park 2008; Saonuam et al. 2008; Tillotson et al. 2008) and the side effects of antibiotic treatment for patients who are allergic to it.
Traditional plant refers to the health practices, approaches, knowledge and beliefs incorporating plant and mineral based medicine to treat, diagnose and prevent illness or maintain well-being (Selvamohan et al. 2012). Several ethnomedicinal plants of Nepal have been identified and their usage documented. These documented plants have been used as antibacterial, antifungal, antiviral and for other general treatments. But, a scientific and systematic investigation on
Date of Submission: August 3, 2018

Published Online: January 2019
Date of Acceptance: November 15, 2018

DOI: https:/ / doi.org/10.3126/tujm.v5i0.22292 
antibacterial properties of Nepalese medicinal plants is still lacking (Rudrappa and Bais 2008).

Antimicrobial agents are essentially important in reducing the global burden of infectious diseases. However, as resistant pathogens develop and spread, the effectiveness of the antibiotics gets diminished. The use of plant extract for medicinal treatment has become popular when people realized that the effective life span of antibiotic is limited and over prescription and misuse of traditional antibiotics are causing microbial resistance (Alam et al. 2009).

The use of crude extracts of plants parts and phytochemicals, of known antimicrobial properties are of great significance in the therapeutic treatments. Extraction is the separation of medically active portions of the plant tissues using selective solvent known as menstruum through standard procedures. The products contain complex mixture of medicinal plant metabolites, such as alkaloids, glycosides, terpenoids, and flavonoids, tannins and lignans. In order to be used as a modern drug an extract may be further processed through various techniques of fractionation to isolate individual chemical entities such as vincristine, vinblastine, hyoscyamine, hyoscine and codeine (Sukhdev et al. 2008).

In this study, an attempt has been made to evaluate the antimicrobial activity of extracts of selected medicinal plants against human pathogenic bacteria and perform minimum inhibitory concentration of plant extracts. This is with a view to contribute knowledge for utilization of locally available medicinal herbs in comparison to the antibiotics which can causes various side effects.

\section{MATERIALS AND METHODS}

Collection of plant samples and bacterial strains: The plant samples were collected from the various areas of Lalitpur, Bhaktapur and Kavrepalanchok district of Nepal and the study was carried out in the laboratory of the Sainik Awasiya Mahavidhayala, Bhaktapur. ATCC strains Escherichia coli, Staphylococcus aureus, Pseudomonas aeruginosa, Salmonella enterica Typhi and Citrobacter freundii obtained from National Public Health Laboratory, Teku were used for antimicrobial activity of plant extracts.

Extraction of antimicrobial compounds: The ethanolic extracts of medicinal plants were prepared by dissolving $20 \mathrm{gm}$ of dried powder into $100 \mathrm{ml}$ of ethanol separately and then kept in the separating funnel for 7 days with continuous shaking in every 24 hours. After 7 days extract was filtered where the sediment settled down at the bottom and left ethanol was evaporated at evaporator. The left over filtrate called as extract containing the chemical constituents of each medicinal plants were dried in the hot air oven at $40^{\circ} \mathrm{C}$ and stored under refrigeration for further use. Whattman's No 3 filter paper was punched into $2 \mathrm{~mm}$ disc and were sterilized. Each disc was soaked in the respective concentration of the extracts that was prepared by using DMSO and methanol in the ratio of 10:90 i.e. 200mg/ $\mathrm{ml}, 100 \mathrm{mg} / \mathrm{ml}, 50 \mathrm{mg} / \mathrm{ml}, 25 \mathrm{mg} / \mathrm{ml}$ and $12.5 \mathrm{mg} / \mathrm{ml}$.

Disc diffusion method: The $20 \mathrm{ml}$ of sterilized Muller Hinton Agar was poured into sterile petri plates, after solidification, $100 \mu \mathrm{l}$ of fresh culture of human pathogens were swabbed on the respective plates. The discs were kept over the agar plates using sterile forceps and incubated at $37^{\circ} \mathrm{C}$ for 24 hours. After incubation the diameter of inhibitory zones formed were measured.

Standardization of bacterial suspension: McFarland standard was used as a reference to adjust the turbidity of bacterial suspensions. The bacterial suspensions were standardized following the CLSI guidelines for aerobic bacteria. All of the tested bacteria were grown in Mueller Hinton broth for 18-24h, followed by the matching of bacterial suspension to the turbidity equivalent to $0.5 \mathrm{McF}$ arland solutions $\left(1-2 \times 10^{8} \mathrm{cfu} /\right.$ $\mathrm{ml})$.

Determination of MIC: The minimum inhibitory concentration (MIC) of the aqueous extract was determined by micro broth dilution method (Andrews JM 2001). For MIC, two-fold serial dilutions of the

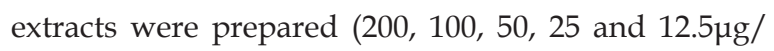
$\mathrm{ml})$. Incubation of the tubes was carried out at $37^{\circ} \mathrm{C}$ for 18-24 hours for bacteria and were observed for any visible growth. The bacterial suspensions were used as positive control and extracts in broth were used as negative control. The MIC was interpreted as the lowest concentration of the extract that did not show any visible growth when compared to control tubes that contained only the extracts.

\section{RESULTS}

In this study, we tested the ethanolic extracts of seven medicinal plants for their antimicrobial activity against human pathogenic bacteria. ATCC strains of Escherichia coli, Staphylococcus aureus, Pseudomonas aeruginosa, 
Salmonella enterica Typhi and Citrobacter freundii were used. All the plants extracts exhibited good antimicrobial properties against the microorganisms tested, as exhibited by disc diffusion method (Table $1)$. At higher concentration $(200 \mathrm{mg} / \mathrm{ml})$, activity was remarkable in comparison to lower one $(12.5 \mathrm{mg} / \mathrm{ml})$.

Extract of C. longa and S. aromaticum showed good antibacterial activity against Escherichia coli with similar zone of inhibition of $11 \mathrm{~mm}$, at concentration of $200 \mathrm{mg} / \mathrm{ml}$. Extract from E. ganitrus, P. guajava and $S$. aromaticum leaves showed most promising result against Staphylococcus aureus with zone of inhibition of 16,16 and $14 \mathrm{~mm}$ respectively at $200 \mathrm{mg} /$ $\mathrm{ml}$ concentration. Pseudomonas aeruginosa was found highly sensitive to the action of $S$. aromaticum $(14 \mathrm{~mm}$ at $200 \mathrm{mg} / \mathrm{ml}$ ) followed by E. ganitrus and A. indica with zone of inhibition of 12 and $11 \mathrm{~mm}$ respectively. At the concentration of $200 \mathrm{mg} / \mathrm{ml}$, extracts of E. ganitrus, S. aromaticum and C. longa were effective against $S$. enterica Typhi with significant zone of inhibition 13, 11, and $10 \mathrm{~mm}$ respectively. Citrobacter freundii was found most sensitive against $S$. aromaticum with inhibition zone $15 \mathrm{~mm}$. On the contrary, C. freundii was resistant against A. indica and A. vulgaris. S. aureus and P. aeruginosa were resistant against $Z$. armatum.

Among the seven medicinal plants, the crude extracts of S. aromaticum, E. ganitrus, C. longa and P. guajava showed good antimicrobial activity against all tested microorganisms. A. indica and A. vulgaris showed good results against Pseudomonas aeruginosa with zone of inhibition $11 \mathrm{~mm}$. Z. armatum was effective against E. coli $(10 \mathrm{~mm})$. MIC values of ethanolic extracts of $S$. aromaticum and E. ganitrus were found to be at the range of $12.5-25 \mathrm{mg} / \mathrm{ml}$.

Table 1: Antimicrobial activity of plant extracts against the human pathogenic bacteria by disc diffusion method.

\begin{tabular}{|c|c|c|c|c|c|c|}
\hline Extract & Concentration & E. coli $(\mathrm{mm})$ & $\begin{array}{l}\text { S. aureus } \\
(\mathrm{mm})\end{array}$ & $\begin{array}{l}\text { P. aeruginosa } \\
(\mathrm{mm})\end{array}$ & $\begin{array}{l}\text { S. enterica } \\
\text { Typhi (mm) }\end{array}$ & $\begin{array}{l}\text { C. freundii } \\
(\mathrm{mm})\end{array}$ \\
\hline \multirow[t]{5}{*}{ S. aromaticum } & $200 \mathrm{mg} / \mathrm{ml}$ & 11 & 14 & 14 & 11 & 15 \\
\hline & $100 \mathrm{mg} / \mathrm{ml}$ & 9 & 11 & 9 & 9 & 7 \\
\hline & $50 \mathrm{mg} / \mathrm{ml}$ & 8 & 9 & - & 7 & 6 \\
\hline & $25 \mathrm{mg} / \mathrm{ml}$ & 6 & 6 & - & 5 & 5 \\
\hline & $12.5 \mathrm{mg} / \mathrm{ml}$ & 5 & 5 & - & - & - \\
\hline \multirow[t]{5}{*}{ C. longa } & $200 \mathrm{mg} / \mathrm{ml}$ & 11 & 9 & 10 & 10 & 9 \\
\hline & $100 \mathrm{mg} / \mathrm{ml}$ & 10 & 8 & 9 & 9 & 8 \\
\hline & $50 \mathrm{mg} / \mathrm{ml}$ & 9 & 6 & 7 & 7 & 7 \\
\hline & $25 \mathrm{mg} / \mathrm{ml}$ & 8 & - & 6 & 6 & - \\
\hline & $12.5 \mathrm{mg} / \mathrm{ml}$ & 6 & - & - & - & - \\
\hline \multirow[t]{5}{*}{ E. ganitrus } & $200 \mathrm{mg} / \mathrm{ml}$ & 9 & 16 & 12 & 13 & 9 \\
\hline & $100 \mathrm{mg} / \mathrm{ml}$ & 7 & 14 & 8 & 10 & 8 \\
\hline & $50 \mathrm{mg} / \mathrm{ml}$ & - & 13 & - & 6 & 7 \\
\hline & $25 \mathrm{mg} / \mathrm{ml}$ & - & 11 & - & 5 & - \\
\hline & $12.5 \mathrm{mg} / \mathrm{ml}$ & - & 10 & - & - & - \\
\hline \multirow[t]{5}{*}{ P.guajava } & $200 \mathrm{mg} / \mathrm{ml}$ & 10 & 16 & 9 & 10 & 9 \\
\hline & $100 \mathrm{mg} / \mathrm{ml}$ & 8 & 9 & 7 & 7 & 8 \\
\hline & $50 \mathrm{mg} / \mathrm{ml}$ & 7 & 8 & - & - & 7 \\
\hline & $25 \mathrm{mg} / \mathrm{ml}$ & - & 7 & - & - & - \\
\hline & $12.5 \mathrm{mg} / \mathrm{ml}$ & - & - & - & - & - \\
\hline \multirow[t]{2}{*}{ A. indica } & $200 \mathrm{mg} / \mathrm{ml}$ & 10 & 7 & 11 & 8 & - \\
\hline & $100 \mathrm{mg} / \mathrm{ml}$ & 9 & 6 & 8 & 7 & - \\
\hline
\end{tabular}




\begin{tabular}{lllllll}
\hline \multirow{2}{*}{ Extract } & Concentration & E. coli $(\mathrm{mm})$ & $\begin{array}{l}\text { S. aureus } \\
(\mathrm{mm})\end{array}$ & $\begin{array}{l}\text { P. aeruginosa } \\
(\mathrm{mm})\end{array}$ & $\begin{array}{l}\text { S. enterica } \\
\text { Typhi }(\mathrm{mm})\end{array}$ & $\begin{array}{l}\text { C. freundii } \\
(\mathrm{mm})\end{array}$ \\
\hline & $50 \mathrm{mg} / \mathrm{ml}$ & 8 & 6 & 7 & 6 & - \\
& $25 \mathrm{mg} / \mathrm{ml}$ & - & - & - & - & - \\
& $12.5 \mathrm{mg} / \mathrm{ml}$ & - & - & - & - & - \\
\hline A. vulgaris & $200 \mathrm{mg} / \mathrm{ml}$ & 9 & 8 & 11 & 8 & - \\
& $100 \mathrm{mg} / \mathrm{ml}$ & 7 & 7 & 8 & 7 & - \\
& $50 \mathrm{mg} / \mathrm{ml}$ & 6 & 6 & 7 & 5 & - \\
& $25 \mathrm{mg} / \mathrm{ml}$ & - & - & - & - & - \\
\hline Z. armatum & $12.5 \mathrm{mg} / \mathrm{ml}$ & - & - & - & 8 & 7 \\
& $200 \mathrm{mg} / \mathrm{ml}$ & 10 & - & - & 7 & 6 \\
& $100 \mathrm{mg} / \mathrm{ml}$ & 8 & - & - & 6 & - \\
& $50 \mathrm{mg} / \mathrm{ml}$ & 7 & - & - & - & - \\
\hline
\end{tabular}

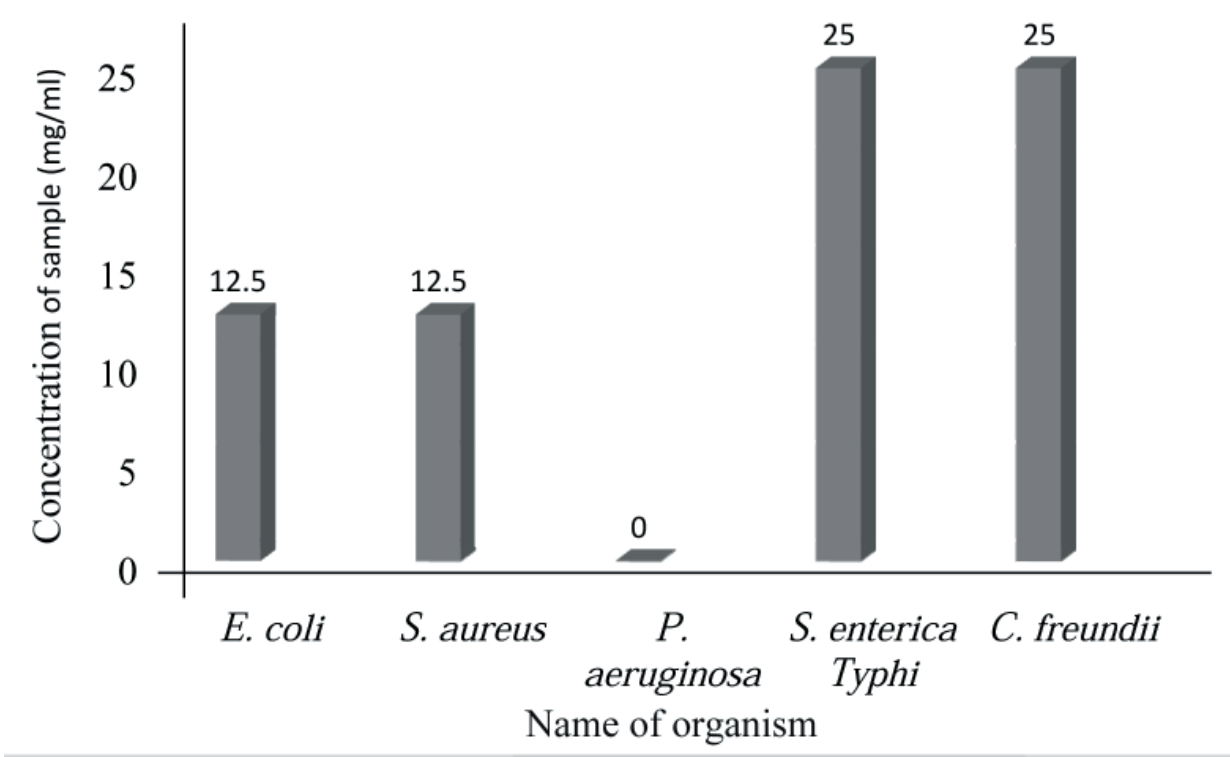

Figure 1: Minimum Inhibitory Concentration (MIC) of S. aromaticum

\section{DISCUSSION}

Medicinal plants are considered as a rich resource of ingredients which can be used in drug development and synthesis. The compounds found in plants are of many kinds, but most are in four major biochemical classes, alkaloids, glycosides, polyphenols, and terpenes. Some plants consider as important source of nutrition while others are recommended for their therapeutic values. These plants include ginger, green tea, walnuts and some others plants (Lichterman 2004). In this study plants Syzygium aromaticum, Curcuma longa, Elaeocarpus ganitrus, Psidium guajava, Azadirachta indica, Artemisia vulgaris and Zanthoxylum armatum were used. Maximum antimicrobial activity was shown by E. ganitrus against S. aureus at all concentrations.

The main component of Syzygium aromaticum is eugenol which is the major component for its antibacterial activity. In this study, it was observed that the ethanolic extracts of $S$. aromaticum has maximum activity against C. freundii $(15 \mathrm{~mm})$ followed by $S$. aureus and $P$. aeruginosa i.e. $14 \mathrm{~mm}$ whereas the least activity was seen in the case of E. coli and S. enterica Typhi i.e.11mm. However, in the study conducted by Maharjan et al. 
(2011) and Wankhede (2015) using E. coli, S. aureus, S. enterica Typhi and $P$. aeruginosa, maximum activity was seen in the case of Salmonella enterica Typhi while least activity was seen in case of $S$. aureus.

Curcuma longa contains curcuminoids, which include mainly curcumin (Chainani 2003), which are believed to be the most important fraction responsible for the biological activities of C. longa. In this study, the maximum activity was seen in case of $E$. coli $(11 \mathrm{~mm})$ followed by P. aeruginosa and S. enterica Typhi (10mm) and minimum activity against $S$. aureus and $C$. freundii each with $9 \mathrm{~mm}$. Similarly, in the study conducted by Maharjan et al. (2011), among E. coli, S. aureus, S. enterica Typhi, P. aeruginosa used in this study, the maximum antibacterial activity was seen against $E$. coli $(15 \mathrm{~mm})$ and lowest antibacterial activity against $S$. aureus $(14 \mathrm{~mm})$ at $100 \mathrm{mg} / \mathrm{ml}$ concentration whereas, no activity was seen against other organisms.

The Elaeocarpus ganitrus fruit have reported to contain many phytoconstituents such as alkaloids, flavonoids, tannins, steroids and triterpenoids. In this study, ethanolic extracts of E. ganitrus was most active against S. aureus $(16 \mathrm{~mm})$ whereas lowest antimicrobial activity was seen against $E$. coli and C. freundii (9mm) in 200mg/ $\mathrm{ml}$ concentration of extracts. According to Kumar et al. (1998), antimicrobial activity of the aqueous extract of leaves of E. ganitrus was tested against clinical isolates of bacteria and fungi where maximum activity was seen in case of $E$.coli $(12.3 \mathrm{~mm})$ and minimum activity was seen in case of $S$. aureus $(11 \mathrm{~mm})$.

The major chemical constituent of Pisidium guajava is said to be tannins. In this study, ethanolic extract of leaves of $P$. guajava showed maximum activity against $S$. aureus $(16 \mathrm{~mm})$ and lowest activity was observed in case of $P$. aeruginosa and C. freundii (9mm) at $200 \mathrm{mg} /$ $\mathrm{ml}$ concentration. Similarly, Neha et al. (2017) screened the antibacterial effects of ethanolic extracts of guava against UTI causing pathogens i.e. S. aureus and E. coli. $P$. guajava leaves showed maximum activity against $E$. coli $(10 \mathrm{~mm})$ while the growth of $S$. aureus was inhibited to a minimum extent $(7 \mathrm{~mm})$.

Terpenes are considered to be the major chemical constituent of Azdirachta indica. In our study, the maximum activity was seen against $P$. aeruginosa $(11 \mathrm{~mm})$ whereas lowest antimicrobial activity was seen against $S$. aureus $(6 \mathrm{~mm})$ at highest concentration of the extracts i.e. $200 \mathrm{mg} / \mathrm{ml}$. Similarly in the study conducted by Brindha et al. (2012) leaf extract showed highest antibacterial activity was detected against $P$. aeruginosa and its lowest antibacterial activity was detected against $S$. aureus.

The active components of Artemisia vulgaris are known to be flavonoids, inulin and traces of alkaloids, and volatile oil. In our study, the highest antimicrobial activity was seen against $P$. aeruginosa $(11 \mathrm{~mm})$ followed by E. coli $(9 \mathrm{~mm})$, S. aureus $(8 \mathrm{~mm})$ and S. enterica Typhi $(8 \mathrm{~mm})$ respectively. Similarly, in the study conducted by Kolume et al. (2011) maximum activity was seen in case of E. coli $(20 \mathrm{~mm})$ whereas least activity was shown by $S$. aureus $(10 \mathrm{~mm})$.

In our study, maximum antimicrobial activity of ethanolic extracts of leaves of Zanthoxylum armatum was seen in case of $E$. coli $(10 \mathrm{~mm})$ and lowest antimicrobial activity in case of $C$. freundii $(7 \mathrm{~mm})$. According to Sadia et al. 2014, maximum antimicrobial activity of $Z$. armatum was observed against $P$. aeruginosa whereas lowest activity was seen against $S$. aureus.

The contradiction in the zone of inhibition may be due to concentration variation, various test environment and methods. On the basis of this finding, the ethanolic extract of plant parts possess a good candidate in the search for a natural antimicrobial agent against infections or diseases caused by the test organisms. The extracts of these plants should be further analyzed to isolate the specific antibacterial properties in them. Clinical trials should be carried out to explore the potential of these plant extracts in the treatment of the infectious diseases.

\section{CONCLUSION}

This study has helped in demonstrating the potential bioactive compound of natural plant extracts that are economical. Among seven extracts examined Snyzygium aromaticum, Pisidium guajava and Elaeocarpus ganitrus showed the best antibacterial activity against $S$. aureus. Based on the results, we may conclude that secondary components of these plants showed antibacterial activity that can be used for the treatment of diseases caused by the organism. This study has helped us to understand the importance of traditional medicine in the treatment of different bacterial disease than antibiotics as it shortens the length of treatment, increase patient compliance as well as reduce overdose which may lead to toxicity or other side effects. 


\section{ACKNOWLEDGEMENTS}

We would like to express our sincere gratitude to Sainik Awasiya Mahavidhyalaya for providing us with laboratory facilities that are required for smooth and efficient passage of work required for the completion of the project. We are also thankful to the supervisors for the proper guidance, support, and encouragement throughout the project.

\section{CONFLICT OF INTEREST}

The authors declare no conflict of interest.

\section{REFERENCES}

Alam MT, Karim MM, and KhanSN (2009). Antibacterial activity of different organic extracts of Achyranthes aspera and Cassia alata. Journal of Scientific Research 1: 393-398.

Brindha S, Maragathavalli S, Kaviyarasi NS, Annadurai BB and Gangwar SK (2012). Antimicrobial activity in leaf extract of neem (Azadirachta indica linn). International Journal of Science and Nature 3(1): 110113.

Chainani WN (2003). Safety and anti-inflammatory activity of curcumin: a component of turmeric (Curcuma longa). J Altern Complement Med 9: 161168.

Dowzicky MJ and Park CH (2008). Update on antimicrobial susceptibility rates among gramnegative and gram-positive organisms in the United States: Results from the tigecycline evaluation and surveillance trial (TEST) 2005 to 2007. Clin Ther 30: 2040-2050.

Kolume DD, Hiremath SK and Muddapur UM (2011). Antimicrobial activity of Artemisia vulgaris Linn (Damanaka). International Journal of Research in Ayurveda and Pharmacy 2(6): 1674-1675.

Kumar G, Karthik L, Rao B and Venkata K (1998). Antimicrobial activity of Elaeocarpus ganitrus Roxb (Elaeocarpaceae): An In vitro study. Elixir International Journal 40: 5384-5387.

Lichterman BL (2004). Aspirin: The Story of a Wonder Drug. Curr Med Chem 11: 1451-1460.

Maharjan D, Singh A, Lekhak B, Basnyat S and Gautam
LS (2011). Study on Antibacterial Activity of Common Spices. Nepal Journal of Science and Technology 12: 312-317.

Neha S, Jana AM, Pathak N, Singh C and Singh P (2017). A preliminary study on the antibacterial effects of ethanolic extract of Psidium guajava leaves on Bacteria isolated from urinary tract infection with special reference to Escherichia coli and Staphylococcus aureus. International Journal of Biotechnology and Biochemistry: 13(2): 83-89

Rudrappa T and Bais HP (2008). Curcumin, a known phenolic from Curcuma longa, attenuates the virulence of Pseudomonas aeruginosa PA01 in whole plant and animal pathogenicity models. $J$ Agric Food Chem 56: 1955-1962.

Sadia A, Abdul M, Shahzad H, Rehman AU, Khan T, Jadoon MA and Rehman MU (2014). Comparative In vitro activity of ethanol and hot water extracts of Zanthoxylum armatum to some selective human pathogenic bacterial strains. International Journal of Biosciences 4(1): 285-291.

Saonuam P, Hiransuthikul NC, Suankratay KM and Danchaivijitr S (2008). Risk factors for nosocomial infections caused by extended-spectrum a-lactamase producing Escherichia coli or Klebsiella pneumoniae in Thailand. Asian Biomed 2: 485-491.

Selvamohan T, Ramadas V and Kishor SSS (2012). Antimicrobial activity of selected medicinal plants against some selected human pathogenic bacteria. Advances in applied science Research 3(5): 3374-3381.

Sukhdev HS, Sumanpreet KS, Longo Gennaro and Dev RD (2008). Extraction Technologies for Medicinal and Aromatic Plants. International Centre for Science and High Technology, Trieste, Italy 6-266.

Tillotson GS, Draghi DC, Sahm DF, Tomfohrde KM, Fabro TD and Critchley IA (2008). Susceptibility of Staphylococcus aureus isolated from skin and wound infections in the United States 200507: Laboratory-based surveillance study. J Antimicrobial Chemother 62: 109-115. 